\title{
Land Use Conflict Between Farmers and Herdsmen - Implications for Agricultural and Rural Development in Nigeria
}

\author{
Rashid Solagberu Adisa \\ Department of Agricultural Extension and Rural Development, \\ University of Ilorin, Ilorin \\ Nigeria
}

\section{Introduction}

Land is probably the most important resource needed by Man for his day-to-day existence. All human livelihoods and activities are directly or indirectly dependent on land at varying thresholds. But land connotes different meanings to the various user groups. For instance, builders, manufacturers, fishermen, miners, hunters and farmers have different specifications in their requirement for land for their production/services. Out of all user groups, agricultural production perhaps exhibits the highest form of sophistication in its use of land. Not only must agricultural land be capable of supplying crop-specific nutrients and water; soil temperature, structure, texture and $p-h$ levels are inevitable requisites in the choice of land for agricultural production activities. Yet, land is a limited, somewhat scarce, resource with both artificial and natural access and usage barriers.

These factors of specifications, multifarious uses of land and its limitedness have necessitated that various shades of competition for its utilization must ensue. Thus, competition for land between and within various user groups has been the bane of mankind since time immemorial. Non-agricultural user groups compete with agricultural usergroups on one hand, while there are various levels of intra-user group competition on the other. Indeed competition for land use is becoming keener and fiercer, largely due to increasing human and animal populations (Gefu and Kolawole, 2002). It has been illustrated that increasing population growth rate has continued to exert great pressure on available land resources with varying environmental and socioeconomic implications (Dietz, Ruben and Verhagen, 2001; Tarhule and Lamb, 2003; Fiki and Lee, 2004).

Farmer-herdsmen conflict has remained the most preponderant resource-use conflict in Nigeria (Ajuwon, 2004; Fasona and Omojola, 2005). The necessity to provide food of crop and animal origin, as well as raw materials for industry and export in order to meet evergrowing demands, has led to both "intensification and extensification" of land use (Nyong and Fiki, 2005). The competition between these two agricultural land user-groups, however, has often times turned into serious overt and covert manifestation of hostilities and social friction in many parts of Nigeria. The conflicts have demonstrated high potential to exacerbate the insecurity and food crisis particularly in rural communities where most of the conflicts are localized, with reverberating consequences nationwide. 


\section{Arable cropping in Nigeria}

According to Lambrou and Laub (2006), 75 percent of today's food comes from 12 arable crops and five animal species, with just three arable crops (rice, maize and wheat) accounting for about 60 percent of the calories and proteins obtained from plants. Worldwide, arable crops enjoy remarkable dominance, playing significant roles in the socioeconomic lives of both rural and urban peoples. Arable crops include a wide range of annual crops of primary importance such as maize, rice, sorghum, millet, cassava, cowpea, wheat, soybeans, melon, groundnut yam, vegetables and so on.

In Nigeria, production of arable crops is essentially the prominent feature of agricultural activities. Indeed, almost all farmers in Nigeria cultivate one or more arable crops for food and income. According to Fayinka (2004), Nigerian agricultural production is dominated by rural-based small scale arable crop producers, who account for about $80 \%$ of total food requirement. In a study on production of some major arable crops in Nigeria, Okuneye et al, (2001) revealed that the average farm size in arable crop production was 4.58 ha. Central Bank of Nigeria, CBN, (2005) reported that 36.25 and 82.41 million hectares of arable crops were cultivated in 2004 and 2005 respectively. The CBN report further stated that production of arable crops increased from 88.3million tones in 2001 to 111.8 million tones in 2005. By far the most widely grown arable crop in Nigeria is maize, accounting for 6.6 and 7.5 million hectares in 2004 and 2005 respectively. Maize is grown almost in every part of the country. Most arable crop farmers rely on rainfall to produce, with farming activities normally beginning as soon as the onset of rains. Apart from being veritable sources of income for farmers; arable crops are processed into other useful items at industrial and household levels.

\section{The cattle herding system in Nigeria}

Cattle herding is dominated almost entirely by the Fulani tribe in Nigeria. Iro (1994) gave a vivid documentation of the herding system of the Fulani in Nigeria, and most of what is presented hereunder was derived from his account. According to him, herding is a daunting task, and contrary to widespread belief, it is not the delight of the Fulani- they herd not as a matter of choice but as a necessity. Iro (1994) found that about $75 \%$ of the sampled nomadic pastoralists maintained that cattle herding is not only toilsome, but also becoming increasingly strenuous.

The optimum Fulani cattle herd size lies between 80 and 100. With a preponderance of female over male at ratio 4:1, the Fulani maintains a balanced functional species composition that is made up of 'beefers, milkers, breeders, carriers, and stock beautifiers'. Iro (1994) also stated that the slow-maturing Sokoto Red cow and the lyre-horned White Fulani cattle are the mainstay of the pastoral Fulani holdings. White and Wickens (1976, cited by Iro, 1994) disclosed that the White Fulani, though less hardy, has higher milk and beef yield compared with the Sokoto Red.

Cattle belonging to individual family members are usually herded together, with male family members assuming automatic rights to all cattle, making it difficult to determine cattle ownership by female family members. Fulani men possessing less than twenty cows are seen as poor, while women having six cows are considered as rich (Iro, 1994). Women, however, own most of the small ruminants and all of the poultry (Swinton, 1987 in Iro, 
1994). Though most Fulani men herd cattle well pass the middle age, herding is dominated by the youths, while decisions about grazing are mainly made by the elderly family members. The Fulani herdsman makes excellent use of sign language, the cane and verbal command to drive the animals, with faster animals occupying the front rows. During migration, a typical herd consisting of several family units move in a column of up to five meters wide and two kilometers long. And by the time it passes any given point, 'everything that stands at that point is destroyed' (Fricke, 1979; and Vengroff, 1980 as cited in Iro, 1994).

Describing the annual herding cycle of the Fulani, Iro (1994) stated that the herding season begins with southward movement of the herd and along rivers and stream valleys from October to December - marking the end of rainy season and beginning of dry season. January to February is the harmattan season that is characterized by longer grazing hours, herd splitting, and more frequent visits to stable water sources. These thus increase southward movement of the herds. The months of March and April are usually the toughest for the herdsman and his cattle, as it is the hottest period in the grazing calendar. In deed, he now herds his cattle only in the evenings and nights (Riesman, 1977, as cited in Iro, 1994). May and June signify the end of dry season and vegetation begins to appear. This also marks the beginning of northward movement of cattle herds. From this period up till September, which is the peak of rainy season, though characterized by cattle-breeding, more milk production and shorter grazing hours, cattle herding coincides significantly with arable crop production. Farmer-herdsmen conflict therefore becomes prevalent during this period.

\section{Causes of farmer-herdsmen conflict}

The causes of farmer-herdsmen conflicts are often not far-fetched. However, there appears to be no consensus among both groups as to the causes of their mutual conflict. According to de Haan (2002), 'destruction of crops by cattle and other property (irrigation equipment and infrastructure) by the pastoralists themselves are the main direct causes for conflicts cited by the farmers, whereas burning of rangelands and fadama and blockage of stock routes and water points by crop encroachment are important direct reasons cited by the pastoralists'. Ingawa, Ega, and Erhabor (1999) reported that the key underlying causes of farmer-herdsmen conflict in Nigeria are:

- Changing resource access rights, whereby traditional access rights to communal grazing and water resources are being obstructed by the individual tenureship of arable farmers. This is particularly severe on the traditional trek routes, which become favorite cropping sites because of their better soil fertility resulting from the concentration of animal manure from the trekking herds in these areas. Within the fadama areas, this is exacerbated by the fragmented nature of the crop plots, which makes prevention of animals straying in the crop plots difficult;

- Inadequacy of grazing resources, as increasing crop cultivation (and increasing commercialization of the crop-residues) and poor management of the existing grazing reserves have resulted in a significant reduction in available livestock feed resources, in particular in the Northern States. Moreover the high value crops introduced by NFDP (tomatoes and onions) produce almost no crop-residues for livestock feeding. Finally, the regulation that twenty percent of the fadama would need to be set aside for grazing (National Agricultural Policy, 1988) has not been adhered to; and 
- Decline in internal discipline and social cohesion, as the adherence to the traditional rules regarding grazing periods, and the authority of the traditional rulers is breaking down. This is exacerbated by increased rent seeking of the formal and traditional authorities in managing resource access.

De Haan (2002) also noted that antagonistic perceptions and beliefs among farmers and herdsmen could compound conflict situation, especially due to failing institutions and fierce competition for resources. Another cause of farmer-herdsmen conflicts is increasing rate of cattle theft which, according to de Haan (2002), is often accompanied by violence. Other perceived causes of farmer-herdsmen conflicts include inequitable access to land, diminishing land resources, antagonistic values among user groups, policy contradictions, and non-recognition of rights of indigenous people Adisa (2011a).

Whatever the causes of farmer-herdsmen conflicts are, it is evident that the conflicts have been of great negative effects. These range from economic effects (such as loss of income/resources/yield) to physical (such as home/farm destruction, bodily injury or death of family member) and socio-psychological effects such as emotional exhaustion, job dissatisfaction (Adisa, 2011a). The causes and effects of farmer-herdsmen conflict have attracted considerable theoretical and empirical analyses, but conflict actors and victims' coping machanisms have not received sufficient attention in the literature (Adisa, 2011b). The main thrust of this chapter is to analyze conflict actors' coping strategies and the implications for rural development in Nigeria. Specifically, this study investigated the:

1. Personal and occupational characteristics of conflict actors

2. Effects of conflict on rural household welfare

3. Types of coping strategies used by conflict actors

4. Factors influencing the use the coping strategies, and

\section{Theoretical considerations}

There seems to be insufficient empirical studies focusing on how farmers and herdsmen perceive and cope with mutual conflict. Zarafshani, Zamani and Gorgievski (2005) actually dwelt on coping strategies of farmers, but their work was focused on post-draught famine stresses. Lazarus' Cognitive Appraisal Model of coping, (Lazarus and Folkman, 1984) provides the theoretical foundation for analysis of coping in this study. Other coping models such as self-regulation model (Leventhal, Nerenz and Steele, 1984), psychomaintenance model (Temoshok, Van Dyke and Zegans, 1983) are found in the literature, they paid little or no attention to coping as a mediator of stressful events, according to Zarafshani, Zamani, and Gorgievski (2005).

According to Lazarus' Model, coping from stresses consists of three processes which are:

i. Primary appraisal - the process of perceiving a situation as a loss, a threat or an opportunity.

ii. Secondary appraisal - the process of conceiving a potential response.

iii. Tertiary appraisal - the process of coping resource appraisal.

Thus, within this framework, the way farmers and herdsmen perceive their mutual conflict is an appraisal. The way they cope, following Lazarus and Folkman (1984), is thus categorized as (a) emotion-oriented, (b) problem-oriented or (c) social support oriented. The foregoing, 
although, is theoretical analysis which is expected to translate, in practical terms, into a means of solving the problems posed by farmer-herdsmen conflict. The real theoretical discussion that is necessary for critical reflection must be represented in a concrete manner as to "almost confuse itself with the practical" (Silva, Almeida, Silveira and Melo, 2005).

\section{Methodology}

The study was conducted in Kwara State, Nigeria. Lying in the middle belt of Nigeria, the state has a land area of 32,500 km sq made of Guinea Savannah vegetation to the south and Derived Savannah to the north. Agriculturally, Kwara State is significant for food production in Nigeria because of its rich soil that supports the cultivation of many crops. The state has a cultivable land area of 2,447, 250ha (Kwara State Planning Commission, 2004). Similarly, it has abundant livestock that comprises of cattle, goats and sheep.

Four-stage cluster random sampling procedure was used to select respondents for the research. Kwara State is one of the states in Nigeria that have recorded high incidence of farmer-herdsmen conflict. Out of the 16 local government areas (LGAs) in the state, 10 are most associated with farmer-herdsmen conflict. Out of these 10, six were randomly selectednamely: Asa, Edu, Ifelodun, Ilorin East, Kaiama, and Moro LGAs. In each LGA, five farming communities were randomly selected making a total of 30 villages. Ten arable crop farmers were randomly selected from each village, thus giving a total of 300 farmers. In each LGA, 10 cattle herdsmen were also randomly selected for data collection. This was done by randomly selecting two herdsmen from five transit camps in each LGA. This gives a total of 60 herdsmen. In all, 360 respondents were selected for the quantitative data collection

Relevant data were collected with the aid structured questionnaire. The Test-retest method was used to determine the reliability of the instrument. This was carried out among 20 respondents that would not be included in the research sample. The value of coefficient of correlation " $r$ " was found to be 0.89 , which implied that the instrument was reliable.

Coping strategies of respondents were measured with 20 items on a 4 point Likert-type scale. These include 10 active problem oriented strategies, seven avoidant (or emotion oriented) strategies and three support seeking strategies (Folkman and Lazarus, 1980; Cooper, Deve and O'Driscoll, 2000). Respondents were asked to indicate how often they used each type of coping strategy to deal with aftermath of conflict and were scored.

Probit analysis was used to determine the influence of respondents' socio economic characteristics on their coping strategies. The three coping strategies that were identified are classified as Problem-oriented coping strategies (POCS), Emotion-oriented coping strategies (EOCS), and Social support-seeking coping strategies (SSCS)

The Probit model assumes that

$$
\operatorname{Pr}(\mathrm{Y}=1 / \mathrm{X}=x)=\Phi\left(x^{\prime} \beta\right)
$$

Where

$\boldsymbol{\Phi}=$ is the cumulative distribution of the standard normal distribution,

$\boldsymbol{\beta}$ are parameters typically estimated by maximum likelihood.

$\mathrm{Y}=$ Binary outcome variable

$\mathbf{X}=\mathrm{A}$ vector of regressors 
The use any of the coping strategies was manifested through a variable Qi such that:

$$
\begin{aligned}
& \mathrm{Qi}=1, \text { if UPOCS } \backslash \mathrm{UEOCS} \backslash \mathrm{USSCS}>\mathrm{ti}, \\
& \mathrm{Qi}=0 \text {, if UPOCS } \backslash \mathrm{UEOCS} \backslash \mathrm{USSCS}<\mathrm{ti},
\end{aligned}
$$

Where $\mathrm{ti}=$ average UPOCS $\backslash$ UEOCS $\backslash$ USSCS which were calculated separately for the two groups.

UPOCS $=$ Use of problem oriented strategies

UEOCS $=$ Use of emotion oriented strategies

USSCS $=$ Use of social support seeking strategies.

The use of each of the three categories of the coping strategies was computed for each respondent, since reconnaissance survey indicated that a combination of strategies is employed by both farmers and herdsmen to cope with conflict in agricultural land use. A three point Likert-type scale was used to measure the use of the strategies. There were ten, six and four items under POCS, EOCS, and SSCS respectively, whereby the respective scores of each respondent were expressed in percentage. The average POCS, EOCS, and SSCS for the farmers as well as those of the herdsmen were determined by using their respective sample sizes as the denominators.

\section{Results and discussion}

\subsection{Personal and occupational characteristics}

Table 1 presents the summary of the personal characteristics of respondents (farmers and herdsmen). The highest percentage of farmers were those within the age range of 36-50 years $(42.3 \%)$, while those below 20 years were the lowest, accounting for just $5.5 \%$. The average age of the farmers was 44 years. Among the herdsmen, the mean age was 29 years while the modal age range was $21-35$ years, accounting for $37.5 \%$. All this indicates, perhaps, that cattle herding attracts more youths than farming. That cattle herding is a male dominated enterprise was evident from the findings as could be observed from Table 1. Consistent with the results of research by Gurung (2006), all respondent herdsmen were male. This is contrary to the findings in respect of the farmers, where about $30 \%$ was female. This may be due to the possibility that farming is easier to practice among women, while for socio-cultural factors, most Fulani women might not take cattle herding as occupation. Table 1 further reveals that the farmers were slightly ahead of the herdsmen in terms of formal education. Indeed, most of the herdsmen had no formal education and none had a tertiary education qualification.

It is interesting to note from Table 1 that the average farmer and herdsman in the sample lived above the poverty line, as they earned the equivalents of $\$ 842.74$ and $\$ 1694.94$ respectively per annum $(\$ 1=\mathrm{N} 120)$. Farmers in the lowest range of annual enterprise income who, incidentally are the majority, may however need to augment their income earnings as they were all leaving below poverty line of $\$ 1$ per day by earning below N43, 800 per annum which is the equivalent of $\$ 1$ per day. This confirms the prevalence of poverty among rural farmers in Nigeria, as noted by Chukwuone and Agwu (2005).

Respondents' family sizes ranged from one (unmarried) to 20 people. The modal range and mean family sizes for farmers were found to be 6-10 and nine people respectively, while 


\begin{tabular}{|c|c|c|c|c|c|}
\hline \multirow[t]{2}{*}{ Variable } & & \multicolumn{2}{|c|}{ Farmers $(n=293)$} & \multicolumn{2}{|c|}{ Herdsmen $(n=56)$} \\
\hline & & Frequency & $\%$ & Frequency & $\%$ \\
\hline \multirow[t]{4}{*}{ Age (years) } & $6-20$ & 16 & 5.5 & 18 & 22.2 \\
\hline & $21-35$ & 67 & 22.8 & 21 & 37.5 \\
\hline & $36-50$ & 124 & 42.3 & 12 & 21.4 \\
\hline & $51-65$ & 86 & 29.4 & 5 & 8.9 \\
\hline \multirow[t]{2}{*}{ Gender } & Male & 206 & 70.3 & 56 & 100.0 \\
\hline & Female & 87 & 29.7 & - & - \\
\hline \multirow[t]{6}{*}{ Educational level } & No formal education & 82 & 28.0 & 36 & 64.3 \\
\hline & Quranic/Nomadic & 16 & 5.5 & 12 & 21.4 \\
\hline & Adult education & 32 & 10.8 & - & - \\
\hline & Primary & 77 & 26.3 & 6 & 10.7 \\
\hline & Secondary & 65 & 22.2 & 2 & 3.6 \\
\hline & Tertiary & 21 & 2.1 & - & - \\
\hline \multirow[t]{6}{*}{ Annual income ( $\left.N^{\prime} 000\right)$} & $1-40$ & 106 & 36.2 & 1 & 1.8 \\
\hline & $41-80$ & 64 & 21.8 & 1 & 1.8 \\
\hline & $81-120$ & 49 & 16.7 & 12 & 21.4 \\
\hline & $121-160$ & 22 & 7.5 & 8 & 14.3 \\
\hline & $161-200$ & 18 & 6.2 & 8 & 14.3 \\
\hline & $201-240$ & 34 & 11.6 & 26 & 46.4 \\
\hline \multirow[t]{3}{*}{ Religion } & Christianity & 104 & 35.8 & - & - \\
\hline & Islam & 167 & 57.0 & 56 & 100.0 \\
\hline & Others & 21 & 7.2 & - & - \\
\hline \multirow[t]{4}{*}{ Family size } & $1-5$ & 59 & 20.2 & 10 & 17.9 \\
\hline & $6-10$ & 128 & 43.7 & 11 & 19.6 \\
\hline & $11-15$ & 83 & 28.3 & 26 & 46.4 \\
\hline & $16-20$ & 23 & 7.8 & 9 & 16.1 \\
\hline
\end{tabular}

Note: Mean age of farmers $=44$ years and for herdsmen $=29.0$; Mean income of farmers $=\mathrm{N} 101,129$ and for herdsmen = N203, 393; while their mean family sizes were 9 (for farmers) and 14 (for herdsmen.) NI20 $=1$ US\$.

Table1. Personal characteristics of farmers and herdsmen in Kwara State, Nigeria, 2008. $(\mathrm{N}=349)$

these figures for herdsmen were 11-15 and 14 people respectively. The implication is that the relatively large family sizes for the two groups may mean more people to cater for and, perhaps also more hands to work on the farm and help with cattle herding.

As discernible from Table 2, the two groups exhibited differing occupational characteristics. While most farmers were small-scale operators, most herdsmen operated on a relatively higher scale. This perhaps explains the gap in their income level as shown earlier on in Table 1. Furthermore, most of the farmers had alternative income-generating activities perhaps to augment their farm income. Interestingly too, about $20 \%$ of the herdsmen were agropastoralists - combining cattle-herding with arable crop production. This group of respondents is particularly unique as they qualify to be classified both as farmers and herdsmen, but are also predominantly ethnic Fulani just like the full nomads. On the other hand, farmers, who are essentially non-Fulani, did not engage in cattle herding as alternative occupation. Table 2 further shows that respondents from both groups were mostly driven by income-generating motive. Contrary to common belief, most farmers $(82 \%)$ in the sample claimed that they farm for the money, not just for food. The desire by the two groups to enhance their income is capable of 'driving' their conflict for land use. 


\begin{tabular}{|c|c|c|c|c|c|}
\hline \multirow[t]{2}{*}{ Variable } & & \multicolumn{2}{|c|}{ Farmers $(n=293)$} & \multicolumn{2}{|c|}{ Herdsmen $(n=56)$} \\
\hline & & Frequency & $\%$ & Frequency & $\%$ \\
\hline \multirow[t]{8}{*}{ Farm size (Ha.) } & $<1$ & 92 & 31.3 & NA & NA \\
\hline & $1-3$ & 50 & 17.1 & NA & NA \\
\hline & $4-6$ & 56 & 19.1 & NA & NA \\
\hline & $7-9$ & 38 & 13.0 & NA & NA \\
\hline & $10-12$ & 21 & 7.2 & NA & NA \\
\hline & $12-15$ & 16 & 5.5 & NA & NA \\
\hline & $16-18$ & 8 & 2.7 & NA & NA \\
\hline & No response & 12 & 4.1 & NA & NA \\
\hline \multirow[t]{5}{*}{ Herd size: } & $1-20$ & NA & NA & 6 & 10.7 \\
\hline & $21-40$ & NA & NA & 16 & 28.6 \\
\hline & $41-60$ & NA & NA & 26 & 46.4 \\
\hline & $61-80$ & NA & NA & 5 & 8.9 \\
\hline & & NA & NA & 3 & 5.4 \\
\hline \multirow[t]{4}{*}{ Alternative occupation: } & None & 99 & 33.8 & 42 & 75.0 \\
\hline & One & 108 & 36.9 & 14 & 25.0 \\
\hline & Two & 69 & 23.5 & - & - \\
\hline & Three & 17 & 5.8 & - & - \\
\hline \multirow[t]{5}{*}{ Production system: } & Rain-fed & 179 & 61.1 & - & - \\
\hline & Irrigation & 62 & 21.2 & - & - \\
\hline & Both & 52 & 17.7 & - & - \\
\hline & Pastoralist & NA & NA & 45 & 80.3 \\
\hline & Agro-pastoralist & NA & NA & 11 & 19.7 \\
\hline \multirow{2}{*}{ Production motive: } & Food & 53 & 18.1 & - & - \\
\hline & Income & 240 & 81.9 & 56 & 100.0 \\
\hline \multicolumn{6}{|c|}{ Farming/herding experience (years): } \\
\hline & $1-5$ & 28 & 9.6 & 10 & 17.9 \\
\hline & $6-10$ & 61 & 20.8 & 26 & 46.4 \\
\hline & $11-15$ & 83 & 28.2 & 14 & 25.0 \\
\hline & $16-20$ & 91 & 31.1 & 4 & 7.1 \\
\hline & $21-25$ & 30 & 10.3 & 2 & 3.6 \\
\hline
\end{tabular}

Note: Mean farm size $=2.8$ Hectares; mean herd size $=41$ cattle; mean farming experience $=13$.7years; and mean herding experience $=9.1$ years .

Table 2. Occupational characteristics of farmers and herdsmen in Kwara State, Nigeria, 2008 $(\mathrm{N}=349)$

\subsection{Effects of conflict on household and rural development}

Most respondents suffered various effects as a result of their mutual conflict. The effects on both sides ranged from physical, economic, to socio-psychological. Table 3 presents the results of the investigation of the socioeconomic effects of conflict among respondents. Conflict outcome experienced was actually determined as the loss, or gain of any of the listed resources. Objectionable as conflicts are, the findings show that both farmers and herdsmen reported a few non-material gains. For instance, while 35\% of farmers and $29 \%$ of herdsmen said they gained in knowledge, $30.0 \%$ and $17.9 \%$ respectively agreed that they gained social support as a result of mutual conflict. The only other item that constituted a 'gain' for both parties was quality of relationship, although the figures were very low: $4.1 \%$ for farmers and $5.1 \%$ for herdsmen. These low figures indicate that mutual conflict affects the quality of social relationships. Moreover, $24.6 \%$ farmers and $12.5 \%$ herdsmen indicated a loss in quality of relationship as a result of conflict. Other non-material resources that were lost included job status ( $55.6 \%$ of farmers and $30.3 \%$ of herdsmen); self esteem $(52.9 \%$ of farmers and $16.9 \%$ of herdsmen); and personal $\backslash$ family health (13.9\% of farmers and $16.1 \%$ of herdsmen). 
Land Use Conflict Between Farmers and Herdsmen -

\begin{tabular}{lcccc}
\hline & \multicolumn{2}{c}{ Loss of } & \multicolumn{2}{c}{ Gain of } \\
\hline Resources & Farmers (\%) & Herdsmen $(\%)$ & Farmers (\%) & Herdsmen (\%) \\
\hline Yield & 85.0 & 8.9 & - & - \\
Household resources & 23.5 & 3.6 & - & - \\
Social support & 4.4 & 3.6 & 30.0 & 17.9 \\
Stored products & 22.5 & 7.1 & - & - \\
Job status & 55.6 & 30.3 & - & - \\
Self esteem & 52.9 & 19.6 & - & - \\
Income & 90.8 & 14.3 & - & - \\
Family $\backslash$ personal health & 13.9 & 16.1 & - & - \\
Knowledge & - & - & 35.3 & 28.6 \\
Quality of relationship & 24.6 & 12.5 & 4.1 & 5.4 \\
\hline
\end{tabular}

Table 3. Percentage Distribution of respondents according their conflict outcome experiences

Loss of material resources were, however, more widespread among farmers. Income loss had the highest relative frequency (91\%) among farmers, followed by loss of yield ( $85 \%)$, household resources $(23.5 \%)$ and stored products $(23 \%)$. On the part of herdsmen, losses whether material or not - were minimal. . Indeed, $14.3 \%, 8.9 \%, 7.1 \%$, and $3.8 \%$ of herdsmen claimed to have suffered losses in respect of their, income, yield, stored products and household resources respectively. However, concerning non-material resources, $30 \%, 20 \%$, and $13 \%$ of herdsmen suffered losses in respect of job status, self esteem, and quality of relationship respectively. These figures in respect of herdsmen were generally far less than those for farmers, meaning that farmers experienced more losses than the herdsmen

The results of the investigation of the socio-psychological effects of conflict on the quality of family lives of both farmers and herdsmen are summarized in Table 4 . Findings confirm the positions of researchers such as Ortega, Johnson, Beeson and Craft (1994), Coelcho (2000), and Bosch (2003) that work related stress could have negative socio-psychological effects on family lives among farmers. Indeed, Ajayi and Allagenyi (2001), Johnson and Johnson (2002) and Daniels (2006) stated in their separate studies that family instability and intense frustration are negative consequences of job related conflicts.

\begin{tabular}{lccc}
\hline & \multicolumn{3}{c}{ Rating Mean Scores } \\
\hline Effects & Farmers & Herdsmen & $\mathrm{t}$-value $(\mathrm{p}<.05)$ \\
\hline Marital dissatisfaction & 3.60 & 2.19 & $2.13^{* *}$ \\
Declining quality of children's education & 3.55 & 1.05 & $2.10^{* *}$ \\
Physical exhaustion & 3.75 & 2.15 & $2.18^{* *}$ \\
Sleepless nights & 3.85 & 3.58 & 1.51 \\
Reduced interest in family matters & 1.40 & 1.25 & 1.05 \\
Anger $\backslash$ anxiety $\backslash$ emotional exhaustion & 3.75 & 3.64 & 0.91 \\
Reduction in food quality $\backslash$ quantity & 3.95 & 1.50 & $2.45^{* *}$ \\
Complaints at home & 3.05 & 1.85 & $2.01^{* *}$ \\
Farm $\backslash$ job abandonment & 1.35 & 1.15 & 0.93 \\
Staying more away from home & 1.38 & 1.05 & 0.12 \\
\hline
\end{tabular}

**Significant at $\mathrm{p}<0.05$, two-tailed paired t-test

Table 4. Results of t-test of variables of socio-psychological effects of conflict between farmers and herdsmen in Kwara State, Nigeria 
Table 4 reveals that both farmers and herdsmen suffered several negative sociopsychological consequences relating to their respective family lives. It could be due to the fact that whatever happens at work could affect what happens at home. According to Potter (1995), it is hardly possible to find a frustrated person at work that is energized at home. These effects were, however, found to be more pronounced among the farmers than herdsmen, probably due to the fact that farmers suffered more losses than herdsmen. Table 11 shows further that herdsmen and farmer differed significantly in their rating mean scores of the socio-psychological effects of mutual conflict on the quality of their respective family lives in five aspects: marital dissatisfaction $(\mathrm{t}=2.79, \mathrm{p}<0.05)$, quality of children's education $(t=2.1, p<0.05)$, physical exhaustion $(t=2.18, p<0.05)$, reduction in quality and quantity of food intake $(t=2.45, p<0.05)$, and complaints at home $(t=2.01, p<0.05)$. The higher rating mean score of marital disaffection observed among farmers might, inter alia, not be unconnected with the higher rate of divorce, about $11 \%$, as seen in Table 1 . Also disturbing is the finding that farmer-herdsmen conflicts affected the proper education of children of respondents, as many farmers claimed to experience difficulties in paying school fees and purchasing textbooks and other school materials. This evidently does not augur well for the sustainable development of the affected children, and is capable of creating further social problems in the future if not timely checked. The fact that reduction in quality and quantity of family food intake was found to be a consequence of farmer-herdsmen conflict, particularly among farmers, might be an indication of food insecurity in rural communities. Although farmers had greater mean scores than herdsmen in all items, there were no significant differences in the effects of conflict on family life in the remaining five aspects as shown in Table 4 . These aspects are: sleepless nights, reduced interest in family affairs, anger, job abandonment, and staying more away from home.

\subsection{Conflict actors' coping strategies}

Coping strategies of respondents were classified into three namely: problem oriented (POCS), emotion oriented (EOCS) and social support seeking coping strategies (SSCS). The use of each strategy among farmers and herdsmen were investigated. Table 5 shows the descriptive statistics of the use of problem oriented strategies among the respondents. Farmers generally used a combination of strategies, as no single strategy is enough to bring the needed succor caused by conflict. Ten strategies were identified, out of which 'use of job experience' (77.8\% for farmers and $55.4 \%$ for herdsmen) was most often used by the respondents. Herdsmen in the sample generally used less of problem-oriented strategies than the farmers. This perhaps is an indication that farmers considered the conflict situation from the 'problem' perspective more than the herdsmen. The herdsmen probably faced less problems or direct consequences of the conflict than the farmers.

Other POCS used by the farmers are: taking up alternative occupation (69.6\%), working harder $(61.8 \%)$, buying food for home consumption (50.5\%), and adopting and taking loans from friends and families (45.0\%). The importance of job experience came to the fore, as respondents claimed to rely on their previous experiences to cope with the conflict situation. It could imply that respondents with long experience may be able to cope better than their colleagues with lesser experience. The fact that half of the farmers claimed to buy foodstuff for home consumption may indicate the severity of the effect of destruction of their farms. The least used POCS was sale of entire farm/herd $(14.7 \%$ for farmers and $3.6 \%$ for herdsmen). This, together with the finding that $62.2 \%$ of the farmers $37.5 \%$ of herdsmen 
Land Use Conflict Between Farmers and Herdsmen -

\begin{tabular}{lccccc}
\hline Strategies & $\begin{array}{c}\text { Used often } \\
\text { Deal (\%) }\end{array}$ & $\begin{array}{c}\text { Used somewhat } \\
(\%)\end{array}$ & $\begin{array}{c}\text { Not used } \\
(\%)\end{array}$ & $\begin{array}{c}\text { Not } \\
\text { applicable }\end{array}$ & $\begin{array}{c}\text { Total } \\
(\%)\end{array}$ \\
Worked Harder & $\mathbf{6 1 . 8}$ & $\mathbf{1 6 . 7}$ & $\mathbf{1 9 . 1}$ & $\mathbf{2 . 4}$ & $\mathbf{1 0 0 . 0}$ \\
& 37.5 & 42.9 & 19.6 & 0.0 & 100.0 \\
Used My Experience & $\mathbf{7 7 . 8}$ & $\mathbf{2 0 . 1}$ & $\mathbf{2 . 1}$ & $\mathbf{0 . 0}$ & $\mathbf{1 0 0 . 0}$ \\
& 55.4 & 35.7 & 7.1 & 3.6 & 100.0 \\
Borrowed money & $\mathbf{4 5 . 0}$ & $\mathbf{3 3 . 8}$ & $\mathbf{2 1 . 2}$ & $\mathbf{0 . 0}$ & $\mathbf{1 0 0 . 0}$ \\
& 3.6 & 9.5 & 86.9 & 0.0 & 100.0 \\
Prepared for the worst & $\mathbf{8 . 8}$ & $\mathbf{2 9 . 4}$ & $\mathbf{6 1 . 8}$ & $\mathbf{0 . 0}$ & $\mathbf{1 0 0 . 0}$ \\
& 33.9 & 32.1 & 28.6 & 5.4 & 100.0 \\
Sold farm/herd & $\mathbf{1 4 . 7}$ & $\mathbf{1 9 . 8}$ & $\mathbf{6 5 . 5}$ & $\mathbf{0 . 0}$ & $\mathbf{1 0 0 . 0}$ \\
& 3.6 & 5.4 & 91.0 & 0.0 & 100.0 \\
Bought food/new herd & $\mathbf{5 0 . 5}$ & $\mathbf{3 5 . 8}$ & $\mathbf{1 3 . 7}$ & $\mathbf{0 . 0}$ & $\mathbf{1 0 0 . 0}$ \\
& 14.3 & 16.1 & 69.6 & 0.0 & 100.0 \\
Sowed less/reduce stock & $\mathbf{2 4 . 2}$ & $\mathbf{1 3 . 1}$ & $\mathbf{6 2 . 7}$ & $\mathbf{0 . 0}$ & $\mathbf{1 0 0 . 0}$ \\
& 6.2 & 17.9 & 72.3 & 3.6 & 100.0 \\
Took another job & $\mathbf{6 9 . 6}$ & $\mathbf{1 4 . 7}$ & $\mathbf{1 4 . 7}$ & $\mathbf{1 . 0}$ & $\mathbf{1 0 0 . 0}$ \\
& 3.6 & 9.0 & 85.6 & 1.8 & 100.0 \\
Tighten farm/herd security & $\mathbf{2 2 . 8}$ & $\mathbf{1 3 . 7}$ & $\mathbf{6 3 . 1}$ & $\mathbf{1 . 4}$ & $\mathbf{1 0 0 . 0}$ \\
& 33.9 & 55.4 & 3.6 & 7.1 & 100.0 \\
Used charms & $\mathbf{8 . 9}$ & $\mathbf{2 4 . 2}$ & $\mathbf{6 5 . 9}$ & $\mathbf{1 . 0}$ & $\mathbf{1 0 0 . 0}$ \\
& 25.0 & 39.3 & 17.8 & 17.9 & 100.0 \\
\hline
\end{tabular}

Figures in bold characters are for farmers, while those in italics are for herdsmen

Table 5. Use of Problem-oriented coping strategies among farmers $(n=293)$ and herdsmen $(n=56 n=56)$ in Kwara State, Nigeria, 2008.

substantially used working harder as a strategy, might indicate the comparative resilience of the respondents in the face of unfavourable situations.

It is worrisome, however, that as much as $24.2 \%$ of the farmers adopted 'sowing less', while only about $6 \%$ of the herdsmen 'reduced' their herd size in order to cope with the effects of their mutual conflict. This obviously translates, especially on the part of farmers, into lesser farm output and consequent reduction in food availability, and may indirectly account for rising food prices. Table 3 further shows that the herdsmen were perhaps more security conscious than the farmers. More than the farmers, herdsmen 'prepared for the worst', 'tightened security', and 'used charms' as coping strategies. This scenario tends to indicate that herdsmen were probably more bellicose than the farmers.

Table 6 summarizes the use of EOCS among the two groups. Accepting the conflict situation/consequences as act of fate was found to be the most commonly used emotionoriented coping strategy as $57.7 \%$ of farmers and $39 \%$ of the herdsmen used it a great deal. The ability to accept the situation with equanimity among groups is not only a psychological coping strategy, but is also capable of reducing the escalation of violent conflict between the two groups. Both also used prayer for peace, indicating their level of religious attachment. Use of drugs or alcohol was the least used EOCS among the farmers. The rate of drug/alcohol use was however higher among the herdsmen. It is instructive to observe that drug/alcohol use as a coping strategy not only portends undesirable health consequences, it could actually worsen the conflict situation by affecting the behavioural orientations of persons concerned. 


\begin{tabular}{lccccc}
\hline Strategies & $\begin{array}{c}\text { Used often } \\
\text { Deal }(\%)\end{array}$ & $\begin{array}{c}\text { Used somewhat } \\
(\%)\end{array}$ & $\begin{array}{c}\text { Not used } \\
(\%)\end{array}$ & $\begin{array}{c}\text { Not } \\
\text { applicable }\end{array}$ & $\begin{array}{c}\text { Total } \\
(\%)\end{array}$ \\
\hline Accepted it as fate & $\mathbf{5 7 . 7}$ & $\mathbf{2 2 . 5}$ & $\mathbf{1 4 . 0}$ & $\mathbf{5 . 8}$ & $\mathbf{1 0 0 . 0}$ \\
& 39.3 & 35.6 & 17.9 & 7.2 & 100.0 \\
Prayed for peace & $\mathbf{2 8 . 3}$ & $\mathbf{6 4 . 8}$ & 5.5 & $\mathbf{1 . 4}$ & $\mathbf{1 0 0 . 0}$ \\
& 51.8 & 32.0 & 10.8 & 5.4 & 100.0 \\
Pretended it wasn't bad & $\mathbf{1 4 . 6}$ & $\mathbf{1 7 . 4}$ & $\mathbf{6 6 . 6}$ & $\mathbf{1 . 4}$ & $\mathbf{1 0 0 . 0}$ \\
& 19.6 & 21.4 & 53.6 & 5.4 & 100.0 \\
Take it out on others & $\mathbf{8 . 9}$ & $\mathbf{2 2 . 2}$ & $\mathbf{6 8 . 9}$ & $\mathbf{0 . 0}$ & $\mathbf{1 0 0 . 0}$ \\
& 9.0 & 17.9 & 71.4 & 1.7 & 100.0 \\
Used drugs $\backslash$ alcohol & $\mathbf{7 . 2}$ & $\mathbf{5 . 5}$ & $\mathbf{8 5 . 3}$ & $\mathbf{2 . 0}$ & $\mathbf{1 0 0 . 0}$ \\
& 17.9 & 21.4 & 48.4 & 3.6 & 100.0 \\
Appease other party & $\mathbf{1 3 . 6}$ & $\mathbf{2 1 . 8}$ & $\mathbf{6 1 . 8}$ & $\mathbf{2 . 8}$ & $\mathbf{1 0 0 . 0}$ \\
& 25.0 & 44.6 & 26.8 & 3.6 & 100.0 \\
\hline
\end{tabular}

Figures in bold characters are for farmers, while those in italics are for herdsmen

Table 6. Use of Emotion-oriented conflict coping strategies among farmers $(n=293)$ and herdsmen $(n=56)$ in Kwara State, Nigeria, 2008

It was also found that pretence was not a common coping tool among the respondents, as only about $14.6 \%$ of farmers and $19.6 \%$ of herdsmen and used it often. This indicates that both groups generally recognize the need to be realistic in the management of their mutual conflict. Taking it out on others means transfer of aggression and it was found not to be commonly used by the two groups. Indeed, about $9 \%$ of each category of respondents claimed to use. This not only corroborates the finding that most respondents accepted the conflict as fate, but also indicates a somewhat low level of mutual belligerency among them. Rate of use of 'appeasement' was higher among herdsmen than farmers. This might indicate that farmers were more at the receiving end and needed to be appeased by the herdsmen. It also, perhaps, shows that the herdsmen might be willing to compensate the obviously aggrieved farmers.

Table 7 illustrates the use of SSCS. It was found that the most commonly used was seeking help from friends and relations (73.1\% of farmers and $59 \%$ of herdsmen) to ameliorate the effects of conflict. It was followed by seeking help from traditional institutions. A vast majority of the respondents in each group did not use litigation as a coping strategy, despite the fact that there are regulations regarding the use of agricultural land in the study area. This may be due to the respondents' lack of awareness of their legal rights or their decision to accept the situation as their 'fate'. Seeking help from local governments was least adopted as a coping strategy by farmers, perhaps because there was no enabling environment for that to occur.

\subsection{Factors influencing the use of coping strategies conflict actors}

Probit analysis was used to ascertain the socioeconomic variables that influenced the use of the coping strategies of farmers and herdsmen. The results are presented in Tables 9-11. Table 8 summarizes the findings in respect of average values of the scores concerning the three coping strategies by respondents in each group. It was found that, among farmers, the average score in the use of problem-oriented strategies was $72.5 \%$, while that for herdsmen was $43.2 \%$. It implies that farmers, on the average, used more of problem-oriented coping strategies than herdsmen did This might be due to the fact that farmers encountered more conflict-related problems than herdsmen. 
Land Use Conflict Between Farmers and Herdsmen Implications for Agricultural and Rural Development in Nigeria

\begin{tabular}{lccccc}
\hline Strategies & $\begin{array}{c}\text { Used often } \\
(\%)\end{array}$ & $\begin{array}{c}\text { Used somewhat } \\
(\%)\end{array}$ & $\begin{array}{c}\text { Not used } \\
(\%)\end{array}$ & $\begin{array}{c}\text { Not } \\
\text { applicable }\end{array}$ & $\begin{array}{c}\text { Total } \\
(\%)\end{array}$ \\
\hline Help from relations & $\mathbf{5 9 . 0}$ & $\mathbf{1 4 . 0}$ & $\mathbf{2 5 . 2}$ & $\mathbf{1 . 8}$ & $\mathbf{1 0 0 . 0}$ \\
& 26.8 & 32.0 & 35.8 & 5.4 & 100.0 \\
Help from local leaders & $\mathbf{1 4 . 7}$ & $\mathbf{1 5 . 0}$ & $\mathbf{6 7 . 9}$ & $\mathbf{2 . 4}$ & $\mathbf{1 0 0 . 0}$ \\
& 7.2 & 7.2 & 85.6 & 0.0 & 100.0 \\
Sought litigation & $\mathbf{1 0 . 9}$ & $\mathbf{7 . 2}$ & $\mathbf{7 9 . 5}$ & $\mathbf{2 . 4}$ & $\mathbf{1 0 0 . 0}$ \\
& 3.6 & 3.6 & 89.2 & 3.6 & 100.0 \\
Help from local government & $\mathbf{4 . 4}$ & $\mathbf{1 6 . 7}$ & $\mathbf{7 5 . 5}$ & $\mathbf{3 . 4}$ & $\mathbf{1 0 0 . 0}$ \\
& 7.2 & 14.3 & 78.5 & 0.0 & 100.0 \\
\hline
\end{tabular}

Figures in bold characters are for farmers, while those in italics are for herdsmen

Table 7. Use of social support as conflict coping strategies among farmers $(n=293)$ and herdsmen $(n=56)$ in Kwara State, Nigeria, 2008

\begin{tabular}{lcc}
\hline Item & Farmers & Herdsmen \\
\hline Average use of problem-oriented strategies score (\%) & 72.5 & 43.2 \\
Average use of emotion-oriented strategies score (\%) & 44.2 & 69.4 \\
Average use of social support-seeking strategies scores (\%) & 68.8 & 21.6 \\
\hline
\end{tabular}

Table 8. Mean scores of the use of coping strategies among farmers and herdsmen in Kwara State, Nigeria, 2008

On the other hand, the average use score in respect of emotion-oriented coping strategies was higher for herdsmen than farmers. Table 8 further shows that while farmers' average social support-seeking strategies score was $68.8 \%$, that of herdsmen was $41.6 \%$. This implies that the farmers had greater tendency to seek external help in order to cope with the effects of conflict than the average herdsmen in the study sample.

The Probit analyses of socioeconomic variables influencing the use of each of the 3 categories of coping strategies (the dependent variable) among farmers and herdsmen are presented in Tables 9-11. The ML- (maximum likelihood) binary probit method was used, with convergence achieved after 5 iterations. At degree of freedom 10 - which is the number of independent variables, the critical LR statistic $\left(\chi^{2}\right)$ is 18.0370 at 0.05 probability level. This means that the calculated LR statistic must be higher than 18.0370 for Probit coefficients for any of the coping strategy categories to be collectively statistically significant at 0.05 probability level.

The results indicate that, with average use of POCS among farmers found to be $72.5 \%$ (Table 6), the likelihood ratio, LR statistic of 23.26 was significant at $p=0.014<0.05$. This implies that, at least one variable was significantly different from zero and that collectively, the coefficients are statistically significant. The collective $\mathrm{R}^{2}$ of 0.4362 was relatively low. This does not indicate that the model is bad or unreliable because, according to Granger and Newbold (1976), Achen (1982) and Gujarati (2004), a high $\mathrm{R}^{2}$ value is not necessarily evidence in favour of a model and a low one is not evidence against it. Judge, et al (1982) equally noted that it is not uncommon to get high $\mathrm{R}^{2}$ but find that some of the regression coefficients are either statistically insignificant or have signs that are contrary to reasonable $a$ priori expectations. Also, Goldberger (1991) stated that what is important is to obtain estimates of the true population regression coefficients and draw statistical inferences about them. Table 9 shows that age $(p=0.008)$, income $(p=0.028)$, Family size $(p=0.025)$ and 
farming experience (0.06) were individually significant and thus influenced the use of POCS by farmers. This means that the use of POCS among farmers increased with age, farm income, family size and farming experience.

On the other hand, the average POCS use score among the herdsmen was $43.2 \%$ (Table 6). Investigation of the use of POCS among herdsmen produced the data contained in Table 9. The variables were also found to be collectively significant (LR statistic $=20.822$; $\mathrm{p}=0.013<0.05)$. However, the significance of educational level, annual income and production system in influencing the use of problem oriented strategies could be noted from their respective p-values. Desire to maximize income could lead to more resort to problem oriented strategies among herdsmen. Educational level however showed inverse coefficient which implies, perhaps, that increasing level of education might encourage less use of POCS among herdsmen. The significance of production system might indicate that, as herdsmen change their production pattern, the use of problem-centered coping strategies increased.

\begin{tabular}{|c|c|c|c|c|c|}
\hline Variables & Coefficient & Standard Error & $\mathrm{P}$ & $\mathrm{R}^{2}$ & Remarks \\
\hline \multirow[t]{2}{*}{ Age } & 0.56 & 0.25 & 0.008 & 0.693 & ** \\
\hline & 0.27 & 0.33 & 0.22 & 0.782 & \\
\hline \multirow[t]{2}{*}{ Gender } & 0.09 & 0.01 & 0.63 & 0.865 & \\
\hline & 0.04 & 0.001 & 0.48 & 0.763 & \\
\hline \multirow[t]{2}{*}{ Educational level } & 0.008 & 0.015 & 0.67 & 0.874 & \\
\hline & -0.021 & $0.005 \circ$ & 0.008 & 0.510 & $* *$ \\
\hline \multirow[t]{2}{*}{ Annual income } & $2.3 \times 106$ & $5.36 \times 10^{-7}$ & 0.028 & 0.712 & $* *$ \\
\hline & 0.189 & $0.032 \%$ & 0.021 & 0.664 & ** \\
\hline Household size & 0.32 & 0.026 & 0.025 & 0.808 & \\
\hline-0.012 & 0.01 & 0.44 & 0.803 & & \\
\hline Farm/herd size & $6.65 \times 10^{-6}$ & $2.5 \times 10^{-6}$ & 0.025 & 0.902 & $* *$ \\
\hline 0.006 & 0.022 & 0.19 & 0.811 & & \\
\hline Production system & 0.008 & 0.002 & 0.118 & 0.909 & \\
\hline 0.046 & 0.025 & 0.04 & 0.712 & ** & \\
\hline \multirow[t]{2}{*}{ Production motive } & 0.032 & 0.233 & 0.69 & 0.911 & \\
\hline & $3.39 \times 10^{-6}$ & $5.2 \times 10^{-6}$ & 0.63 & 0.826 & \\
\hline \multirow{4}{*}{$\begin{array}{l}\text { Farming/ herding } \\
\text { experience } \\
\text { Land tenure }\end{array}$} & -0.049 & 0.01 & 0.016 & 0.831 & ** \\
\hline & 0.041 & 0.01 & 0.711 & 0.844 & \\
\hline & -0.008 & 0.022 & 0.496 & 0.933 & \\
\hline & $-7.14 \times 10^{-5}$ & $2.11 \times 10^{-5}$ & 0.55 & 0.905 & \\
\hline \multirow[t]{2}{*}{ Constant } & -0.057 & 0.349 & 0.91 & & \\
\hline & -0.063 & 0.444 & 0.832 & & \\
\hline \multicolumn{3}{|c|}{$\begin{array}{l}\text { LR statistic }(10 \mathrm{df})=\mathbf{1 8 . 2 6 1 1} ; 20.822 \\
\text { Probability }(\text { LR stat })=\mathbf{0 . 0 1 4} ; 0.013\end{array}$} & McFadd & llective) & $62 ; 0.4159$ \\
\hline
\end{tabular}

Figures in bold characters are for farmers, while the italics are the herdsmen

** Significant at $\mathrm{p}=0.05$

Table 9. Socioeconomic factors influencing the use 'problem-oriented' coping strategies among farmers and herdsmen in Kwara State, Nigeria, 2008

The average EOCS use score (tiEOCS) among farmers was found to be $44.2 \%$ a shown in Table 8. Table 8 illustrates the results of the probit analysis of the use of emotion oriented strategies. An LR statistic (i.e. chi-square value) of 19.32 and $p=0.0021<0.05$ showed that at least one variable was significantly different from zero and the variables were collectively 
significant in influencing the use of EOCS among the farmers in the study sample. Age, farm size and farming experience were found to be individually significant in influencing the use of EOCS among farmers. As farm size increased, the use of EOCS also increased.

The significance of farm size in influencing the use of EOCS among the farmers might be due to the fact that increasing farm size requires more commitment from the farmer and he thus becomes more attached to the farm materially, physically and emotionally. $\mathrm{He}$ therefore uses every affordable strategy to combat actual and potential farm-related threats. Age and farming experience, however, recorded negative coefficients which connotes inverse relationship with the use of EOCS among farmers. Farming experience and age, which are interrelated, increased with decreasing use of EOCS among the farmers, suggesting that they relied on more realistic coping strategies, other than emotional ones, with increasing age and farming experience.

\begin{tabular}{|c|c|c|c|c|c|}
\hline Variables & Coefficient & Standard Error & $\mathrm{P}$ & $\mathrm{R}^{2}$ & Remarks \\
\hline \multirow[t]{2}{*}{$\overline{\text { Age }}$} & -0.46 & 0.21 & 0.031 & 0.524 & *** \\
\hline & -0.45 & 0.01 & 0.103 & 0.913 & ** \\
\hline \multirow[t]{2}{*}{ Gender } & 0.09 & 0.25 & 0.45 & 0.812 & \\
\hline & 0.04 & 0.21 & 0.19 & 0.922 & \\
\hline \multirow[t]{2}{*}{ Educational level } & 0.044 & 0.01 & 0.26 & 0.786 & \\
\hline & 0.032 & 0.0018 & 0.32 & 0.904 & \\
\hline \multirow[t]{2}{*}{ Annual income } & $6.2 \times 10^{-7}$ & $2.38 \times 10^{-6}$ & 0.39 & 0.824 & \\
\hline & $2.20 \times 10^{-6}$ & $6.21 \times 100^{6}$ & 0.17 & 0.844 & \\
\hline \multirow[t]{2}{*}{ Household size } & 0.20 & 0.02 & 0.226 & 0.792 & \\
\hline & 0.006 & 0.02 & 0.23 & 0.861 & \\
\hline \multirow[t]{2}{*}{ Farm/herd size } & $2.60 \times 10^{-6}$ & $9.52 \times 10$ & 0.045 & 0.618 & ** \\
\hline & 0.053 & 0.028 & 0.74 & 0.624 & \\
\hline \multirow[t]{2}{*}{ Production system } & 0.005 & 0.326 & 0.52 & 0.861 & \\
\hline & $9.1 \times 10^{7}$ & $2.4 \times 10^{-6}$ & 0.66 & 0.938 & \\
\hline \multirow[t]{2}{*}{ Production motive } & 0.05 & 0.031 & 0.81 & 0.901 & \\
\hline & 0.045 & 0.003 & 0.31 & 0.925 & \\
\hline Farming/herding & -0.043 & 0.01 & 0.042 & 0.773 & ** \\
\hline Experience & -0.037 & 0.015 & 0.027 & 0.832 & ** \\
\hline \multirow[t]{2}{*}{ Land tenure } & 0.001 & 0.026 & 0.83 & 0.914 & \\
\hline & 0.005 & 0.25 & 0.48 & 0.910 & \\
\hline \multirow[t]{2}{*}{ Constant } & -0.059 & 0.488 & 0.847 & & \\
\hline & -0.55 & 0.323 & 0.799 & & \\
\hline \multicolumn{2}{|c|}{$\begin{array}{l}\text { LR statistic }(10 \mathrm{df})=\mathbf{1 5 . 3 2 4} ; 16.624 \\
\text { Probability }(\text { LR stat })=\mathbf{0 . 0 0 2 1} ; 0.033\end{array}$} & \multicolumn{4}{|c|}{ McFadden $\mathrm{R}^{2}$ (collective) $=\mathbf{0 . 3 1 2 6} ; 0.6412$} \\
\hline
\end{tabular}

Figures in bold characters are for farmers, while the italics are the herdsmen

** Significant at $\mathrm{p}=0.05$

Table 10. Socioeconomic factors influencing the use 'emotion-oriented' coping strategies among farmers and herdsmen in Kwara State, Nigeria, 2008

Among herdsmen, socioeconomic characteristics were also found to significantly influence the use of emotion-oriented coping strategies, as indicated by the result of the probit analysis presented in Table 10. With p-value of $0.033<0.05$ and LR statistic of 22.624, the variables under consideration were collectively significant. Specifically, years of herding experience among the respondents increased the probability of using emotion oriented coping strategies. Also, with increasing age, the tendency to use EOCS was found to increase. 
The use of SSCS among farmers was found to be influenced also by educational level, farm size and farming experience (Table 11). The average SSCS USE score among farmers was $68.8 \%$ The LR statistic $(19.1332)$ and probability value $(0.0028<0.05)$ both indicate the collective significance of the variables in influencing the use of SSCS among farmers. With increasing level of education, farmers perhaps become more aware of social support possibilities, and therefore, adopt SSCS. Increasing farming experience and farm size among farmers might also increase their social support seeking abilities. It is also clear from Table 9 that with an LR statistic of 3.327 and a p-value of $0.0641>0.05$, these variables are not collectively significant in influencing the use of social support-seeking strategies among the herdsmen. The reason for this might be that herdsmen generally did not use social supportseeking strategies to cope with conflict.

\begin{tabular}{|c|c|c|c|c|c|}
\hline Variables & Coefficient & Standard Error & $\mathrm{P}$ & $\mathrm{R}^{2}$ & Remarks \\
\hline \multirow[t]{2}{*}{ Age } & 0.33 & 0.01 & 0.363 & 0.810 & \\
\hline & 0.25 & 0.015 & 0.82 & & \\
\hline \multirow[t]{2}{*}{ Gender } & 0.21 & 0.21 & 0.004 & 0.844 & \\
\hline & 0.019 & 0.01 & 0.36 & & \\
\hline \multirow[t]{2}{*}{ Educational level } & $2.17 \times 106$ & $9.66 \times 10$ & 0.032 & 0.665 & ** \\
\hline & 0.021 & 0.028 & 0.22 & & \\
\hline \multirow[t]{2}{*}{ Annual income } & $-6.5 \times 106$ & $2.25 \times 10$ & 0.46 & 0.883 & \\
\hline & 0.006 & 0.01 & 0.16 & & \\
\hline \multirow[t]{2}{*}{ Household size } & 0.45 & 0.025 & 0.62 & 0.904 & \\
\hline & 0.023 & 0.25 & 0.62 & & \\
\hline \multirow[t]{2}{*}{ Farm/herd size } & -0.005 & 0.234 & 0.026 & 0.721 & ** \\
\hline & 0.044 & 0.03 & 0.77 & & \\
\hline \multirow{2}{*}{ Production system } & 0.033 & 0.028 & 0.87 & 0.923 & \\
\hline & $2.7 \times 100^{7}$ & $9.3 \times 10^{7}$ & 0.43 & & \\
\hline \multirow[t]{2}{*}{ Production motive } & 0.019 & 0.015 & 0.72 & 0.872 & \\
\hline & -0.015 & 0.22 & 0.28 & & \\
\hline \multirow{2}{*}{$\begin{array}{l}\text { Farming/herding } \\
\text { experience }\end{array}$} & 0.327 & 0.02 & 0.009 & 0.863 & ** \\
\hline & 0.003 & 0.015 & 0.81 & & \\
\hline \multirow[t]{2}{*}{ Land tenure } & -0.031 & 0.01 & 0.021 & 0.913 & \\
\hline & 0.001 & 0.023 & 0.53 & & \\
\hline \multirow[t]{2}{*}{ Constant } & -0.048 & 0.513 & 0.921 & & \\
\hline & -0.69 & 0.318 & 0.906 & & \\
\hline \multicolumn{2}{|c|}{$\begin{array}{l}\text { LR statistic }(10 \mathrm{df})=\mathbf{1 9 . 1 3 3 2} \\
\text { Probability }(\text { LR stat })=\mathbf{0 . 0 0 2 8}\end{array}$} & \multicolumn{3}{|c|}{ McFadden $\mathrm{R}^{2}($ collective $)=\mathbf{0 . 4 5 2 2}$} & \\
\hline
\end{tabular}

Figures in bold characters are for farmers, while the italics are the herdsmen

** Significant at $\mathrm{p}=0.05$

Table 11. Socioeconomic factors influencing the use 'social support' coping strategies among farmers and herdsmen in Kwara State, Nigeria, 2008

\section{Conclusion and policy implications}

Conflict between arable crop farmers and cattle herdsmen over the use of agricultural land is still pervasive in Nigeria, and portends grave consequences for rural development. It has demonstrated great potential to affect various aspects of rural life. The conflicts had far reaching economic, production and socio-psychological effects on the households of most respondents. However, conflict actors and persons affected have used many strategies to cope 
with the effects of conflict. While farmers generally tended to use problem-oriented strategies, herdsmen basically used emotion-oriented strategies. This might be an indication of a strong emotional attachment to the cattle among the Fulani tribe in Nigeria. Similarly, the relatively more pronounced use of problem-oriented strategies among the farmers is an indication that they actively sought solutions to the problems arising from the destructions they encountered. The sparse use of social support strategies among both groups suggests there were few avenues for victims of land-use conflict to seek social support. Several factors were responsible for the use of coping strategies among the two groups. Age, income, farm size and farming/herding experience significantly influenced the use of most of the coping strategies among the respondents. An increase in any of these variables increased respondents' propensity to use, especially, most of the problem-oriented and emotion-oriented coping strategies. The use of emotion-oriented strategies among herdsmen, however, decreased with increasing educational status. Thus, the tendency to be emotionally 'attached to the cattle' diminished with increasing years of education among herdsmen.

Farmer-herdsmen conflicts have persisted for far too long and the various strategies adopted by both groups have brought little or no progress in dousing the tide and impacts of the conflicts. It is important for both groups to adopt more realistic coping strategies. Coping strategies should be incorporated into the mainstream activities of farmer-herdsmen conflict management. Furthermore, the following recommendations are also proffered for

1. There is need for educational intervention in farmer-herdsmen conflict. This could be achieved by

a. creating better awareness of land use regulations among farmers and herdsmen.

b. availing extension personnel with conflict coping mechanisms through attendance of related seminar and conferences. By so doing, extension personnel would be able to teach farmers and herdsmen on conflict coping mechanisms,

c. educating both parties on the need for peaceful co-existence and mutual understanding,

d. the work of extension is not limited to teaching of new techniques, it is also instructive to know the obstacles that could stand in the way of the techniques to be adopted by farmers. It is therefore worthwhile for extension agencies to have units responsible for farmer-herdsmen relations,

2. Education among the two parties should be realistically encouraged. This would not only lead to better perception but also create better opportunity for awareness of realistic coping strategies,

3. There is need for viable NGOs on farmer-herdsmen conflict management, especially in the areas of awareness, education, prevention, and amelioration. Furthermore, nongovernmental organizations should support livestock-centered livelihoods including cattle herding, not only in conflict mitigation but also in the support of grassroots innovations and in influencing favourable national policies.

4. A multi-stage conflict management framework is required to curb the danger posed by farmer-herdsmen conflict. The proposed framework should be statutory committees at community, local, state, and federal government levels. It should also include the relevant occupational unions.

5. Traditional and local leaders should be well involved in finding solutions to farmerherdsmen conflict. The committees proposed above must have representatives of the local leadership. 


\section{References}

Achen, C. H. (1982) Interpreting and Using Regressions. Sage Publications. Beverley Hills, California.

Adisa, R. S. (2011a). Management of Farmer-herdsmen Conflict in North-Central Nigeria: Implications for Collaboration between Agricultural Extension Service and Other Stakeholders. Journal of International Agricultural Education and Extension, 18 (1): 6072.

Adisa, R. S. (2011b). Patterns of Conflict and Socio-psychological Coping Strategies among Natural Resource User-groups in Tourism Communities of the Nigerian Savannah. The Journal of Tourism and Peace Research, 1 (3): 1-15.

Ajayi, A. R. and Allagenyi, L. D. (2001) Organizational Factors in Sustainable Extension Service Delivery in Nigeria: The Effects of Job-related Stress on Organization Involvement and Quality of Family-life of Extension Agents of Benue State Agricultural Development Programme. Journal of Agricultural Extension, Vol. 5, pp. 9-21

Ajuwon, S. S. (2004) Case Study: Conflict in Fadama Communities. In Managing Conflict in Community Development. Session 5, Community Driven Development.

Bosch, A. (2003). Older People in Disaster: A Comparison of Black and White Victims. International Journal of Aging and Human Development, 26, 29-43.

Central Bank of Nigeria, CBN, (2005). Annual Reports and Statement of Accounts. Abuja, Nigeria.

Chukwone, N. A. and Agwu, A. E. (2005). Financing Agricultural Technology Delivery in Nigeria: Would Farmers be willing to Pay? Journal of Extension Systems, Vol. 22, No.2. Pp.69-85

Coelho, A. E. L. (2000). Psychological Response to Drought in Northwestern Brazil: An Exploratory study. Unpublished Doctoral Dissertation, University of Manitoba, Manitoba, Canada.

Cooper, C.O., P.J. Dewe; and M. P. O’Driscoll (2001). Organizational Stress. A Review and Critique of Theory, Research and Applications. London, Sage Publications.

Daniels, A. M. (2006). Farming, Ranching and Stress: It's a Family Issue. Extension Extra, ExEx 14058. South Dakota State University Cooperative Extension. Pp. 1-4

De Haan, C. (2002). Nigeria Second Fadama Development Project (SFDP), Project Preparation Mission Report, Livestock Component, World Bank. Pp1-13.

Dietz, A. J; R. Ruben and A. Verhagen (2001). Impacts of Climate Change on Drylands with a Focus on West Africa. Dutch National Research Programme on Global Air Pollution and Climate Change, Report No. 410200076. Wageningen: KCD Economic Intelligence Unit Annual Reports (1990, 2004, 2005).

Fasona, M. J. and Omojola, A. S. (2005). "Climate Change, Human Security and Communal Clashes in Nigeria." Paper at International Workshop in Human Security and Climate change, Holmen Fjord Hotel, Oslo Oct. 21-23, 2005.

Fayinka, F. A. (2004). Food Security in Nigeria: Challenges under Democratic Dispensation. Paper Presented At 9th ARMTI Annual Lecture, March 24, 2004.

Fiki, C. and B. Lee (2004). “Conflict Generation, Conflict Management and Self-organizing Capabilities in Drought-prone Rural Communities in North-eastern Nigeria: “A case study". Journal of Social Development in Africa, 19(2): 25-48. 
Folkman, S. and Lazarus, R. S. (1980). An Analysis of Coping in a Middle-aged Community Sample. Journal of Health and Social Behaviour. 21, 219-239.

Gefu, J.O. and A. Kolawole (2002). "Conflict in Common Property Resource Use: Experiences from an Irrigation Project". Paper Prepared for 9th Conference of the International Association for the Study of Common Property. Indiana. [Retrieved in Oct, 2005 from $h t t p: / / d / c$. dlib. Indiana.edu/achive/00000823/00/gefuj080502.pdf]

Goldberger, A. S. (1991) A Course in Econometrics. Harvard University Press. Cambridge, Mass.

Granger, C; and P. Newbold (1976). R2 and the Transformation of Regression Variables. Journal of Econometrics, Vol. 4. Pp.204-210

Gujarati, D. N. (2004) Basic Econometrics. Tata-McGraw-Hill Edition. Pp. 222-223.

Gurung, J. (2006). Gender and Diversification: Expanding Roles for Women to Restore Drylands. International Fund for Agricultural Development, (IFAD). Rome.

Ingawa, S. A; Ega, L. A; and Erhabor, P. O. (1999). Farmer-Pastoralist Conflict in Core-states of the National Fadama Project, FACU, Abuja.

Iro, I. (1994). The Fulani Herding System, Washington, African Development Foundation.

Johnson, D. W. and Johnson, F. P. (2000). Joining Together: Group Theory and Group Skills (7th Edition), Boston, Allyn, and Bacon.

Judge, G. G; Hill, G. R; Griffiths, W. E; Lutkephol, H; and Lee, T. C. (1982). Introduction to the Theory and Practice of Econometrics. John Willey: New York.

Kwara State Planning Commission KSPC. (2005). State Economic Empowerment and Development Strategy (SEEDS) Document. Pp.16-32

Lambrou, Y. and R. Laub (2006). Gender, Local Knowledge, and Lessons Learnt in Documenting and Conserving Agrobiodiversity. WIDER Research Paper; RP2006/69. Helsinki. UNU-WIDER.

Lazarus, R. S. and S. Folkman (1984). Stress, Appraisal and Coping. New York, Springer Publishing Company.

Leventhal, H; D. Nerenz and D, Steele (1984). Illness and Presentations and Coping with Health Threats. In Banm, et al (eds). Handbook of Psychology and Health iv: Social Psychology Aspect of Health Hillsdale, N.J: Erlbaum Associates.

Nyong, A and Fiki, C. (2005). "Droughts-Related Conflicts, Management and Resolution in the West African Sahel." Human Security and Climate change International Workshop. Oslo; GECHS, CICERO and PR20.

Ortega, S. T; Johnson, D. R; Beeson, P. G; and Craft, B. J. (1994). The Farm Crisis and Mental Health: A Longitudinal Study of the 1980s. Rural Sociology, 59, 598-619.

Potter, B.A. (1995). Preventing Job Burnout, 2nd Edition, Crisp Learning Publishers, UK.

Silva, R; Almerda, P; Silviera, L; and M. R.. Melo (2005). "Small-scale Agriculture and Food Security Policies." In LEISA Practice and Policy Anerss foort, ILIEA. Pp 12-13.

Tarhule, A and P.J. Lamb (2003). Climate Research and Seasonal Forecasting for West Africans: Perceptions, dissemination, and use. Bulletin of American Meteorological Society. Vol. 84. 1741-1759.

Temoshok, L., C. Vandyke and L.S. Zeagans, (1983). Emotions in Health and Illness: Theoretical and Research Foundations. Orlando, F.L: Grune and Stralton. 
Zarafshani, K, Gh. H, Zamani; and M. J. Gorgievski (2005). Perceptions and Psychological Coping Strategies of Farmers toward Drought: Implications for Extension Professionals. Journal of Extension Systems, Vol. 21. No. 1, pp.57-71. 


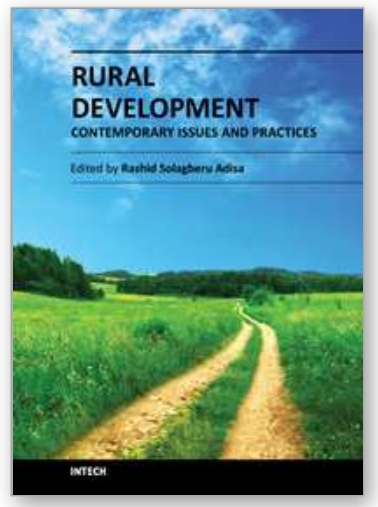

\author{
Rural Development - Contemporary Issues and Practices \\ Edited by Dr. Rashid Solagberu Adisa
}

ISBN 978-953-51-0461-2

Hard cover, 408 pages

Publisher InTech

Published online 20, April, 2012

Published in print edition April, 2012

Development of rural areas has witnessed increasing attention globally, especially over the past three to four decades. The highpoint in the renewed global interest in the development of rural people and their environment was reached with the setting of the Millennium Development Goals (MDGs) in the year 2000. All of the set goals are basically rural development goals. With less than four years to the deadline for the achievement of the MDGs, it is almost certain that the goals are far from being achieved in, especially, most developing countries for whom the MDGs were essentially set. The struggle thus continues for rural development. As long as problems of poverty, disease, illiteracy, unemployment, poor infrastructure, environmental degradation and others persist (or increase) in rural communities, better and more resultoriented solutions to perennial and emerging problems of rural communities would be required. But rural development, in spite of the variations in thresholds of rurality among nations, is not exclusively a Third World or \&lsquo;developing countries\&rsquo; process, owing to its multi-dimensionality. It is a global phenomenon that obviously requires global strategies. This book not only looks at rural development from its multidimensional perspectives, it is also a product of the experiences and expertise of distinguished scholars across the continents. Aiming to provide a comprehensive single volume that addresses salient issues and practices in rural development, the book covers themes ranging from sustainable agriculture, biodiversity conservation, strategic environmental assessment, renewable energy, rural financial resources, assessment of protected areas to statistics for rural development policy. Other subject matters covered by the book include social marginality, land use conflict, gender, cooperatives, animal health, rural marketing, information and communication technology, micro-business, and rural economic crisis. The book is thus an invaluable source of useful information on contemporary issues in rural development for researchers, policy makers, and students of rural development and other related fields.

\title{
How to reference
}

In order to correctly reference this scholarly work, feel free to copy and paste the following:

Rashid Solagberu Adisa (2012). Land Use Conflict Between Farmers and Herdsmen - Implications for Agricultural and Rural Development in Nigeria, Rural Development - Contemporary Issues and Practices, Dr. Rashid Solagberu Adisa (Ed.), ISBN: 978-953-51-0461-2, InTech, Available from: http://www.intechopen.com/books/rural-development-contemporary-issues-and-practices/land-use-conflictbetween-famers-and-herdsmen-implications-for-agricultural-and-rural-development-in

\section{INTECH}

open science | open minds 


\section{InTech Europe}

University Campus STeP Ri

Slavka Krautzeka 83/A

51000 Rijeka, Croatia

Phone: +385 (51) 770447

Fax: +385 (51) 686166

www.intechopen.com

\section{InTech China}

Unit 405, Office Block, Hotel Equatorial Shanghai No.65, Yan An Road (West), Shanghai, 200040, China

中国上海市延安西路65号上海国际贵都大饭店办公楼 405 单元 Phone: +86-21-62489820

Fax: +86-21-62489821 
(C) 2012 The Author(s). Licensee IntechOpen. This is an open access article distributed under the terms of the Creative Commons Attribution 3.0 License, which permits unrestricted use, distribution, and reproduction in any medium, provided the original work is properly cited. 